\title{
FISCAL DECENTRALIZATION - WORLD EXPERIENCE AND OUR PRACTICE
}

\author{
Aleksandar Stojanović \\ University of East Sarajevo, Faculty of Economics, Pale, \\ Bosnia and Herzegovina
}

\section{SUMMARY}

Although it is yet to be systematically investigated where the initiative for fiscal decentralization came from, limited evidence suggests that decentralization offers great opportunities to improve the delivery of public services, and that the result depends on the type of decentralization that has been implemented and the institutions that implement it. Not rare are the examples that decentralization is implemented haphazardly without a proper legal framework and clearly defined rules or is simply imported from another country, without taking into account whether the local authorities in the country are able to carry out their responsibilities. Decentralization is often a matter of political reality, and in itself, it is neither good nor bad.

Fiscal decentralization is especially topical in many countries due to fears of further growth in public spending. Data on the extent of public spending in most countries, especially in the last two decades show the constant increase in public spending in GDP. The results of numerous studies on the subject indicate the high degree of correlation between fiscal decentralization and growth of public spending in a way that centralization is associated with a greater share of public spending in GDP. Therefore, a part of the professional community has long held the view that fiscal decentralization contributes to greater efficiency in the allocation of resources and reduces the amount of public spending.

Keywords: fiscal system. fiscal policy, fiscal decentralization, fiscal autonomy.

\section{INTRODUCTION}

Fiscal decentralization is the most complex form of decentralization. This decentralization leaves to lower levels to make financial decisions and influence over the budget, because if the lower levels of government are transferred the responsibility for carrying out certain functions it is necessary to facilitate their access to sources of income from which they will generate enough funds to cover the costs incurred in connection with these functions. In carrying out fiscal decentralization the expenditure and the revenue are taken into account. The main issues included in fiscal decentralization are ${ }^{1}$ : distribution of income, allocation of expenditures, imbalance in fiscal capacities and in needs of political and territorial units of the same level of government.

Fiscal decentralization, in terms of public revenues, requires solution of two basic questions: what is the level of government responsible for the introduction of specific public revenues (the question of responsibility for the introduction) and secondly, how will the issue of allocation of public revenues be resolved by levels of political and territorial organization (the issue of allocating).

Therefore, when it comes to measuring the autonomy in the sphere of public revenue, the following should be born in mind:

- The tax base for local taxes may not be mobile at the interregional plan because otherwise taxpayers would migrate from

${ }^{1}$ Radičić, M., Raičević, B., Javne finansije - teorija i praksa, Ekonomski fakultet, Novi Sad, 2008 
the local communities in which tax rates are higher to communities where they are cheaper.

- Local taxes should be clear and easy to see, as they finance public expenditures of local character.

- Local taxes should provide sufficient income and be stable in order to meet the needs of the local community.

- Local taxes should be as simple as possible in tax and administrative sense to make collection costs and payments expenses as low as possible.

- Local taxes should not be progressive because it could lead to a migration of wealthy taxpayers.

Measuring the autonomy of public expenditure starts from the assumption that fiscal autonomy implies a certain flexibility of local governments to decide, within the budgetary constraints, on priorities in the implementation of their public expenditures. One of the necessary preconditions for successful decentralization of local government is that local authorities have enough administrative and technical capabilities to effectively carry out activities and tasks. Well placed budget system, the existence of effective local authority for collection of public revenues and appropriate mechanisms for ensuring coordination and cooperation between different levels of government both in the political and in the technical sense of the word, have a key role in the functioning of the system with a number of government levels.

\section{WORLD TRENDS}

Dillinger states that as many as 63 out of 75 developing countries with a population greater than 5 million started some form of transfer of fiscal powers from central government to lower levels of government (fiscal decentralization). ${ }^{2}$

In the UK, which had a centralized fiscal system, the pressure of London for greater independence threatened potential weakening of the unity of the unitary Britain in a multinational framework. The UK government, after the victory of Tony Blair in 1997, in accordance with a program that included a radical constitutional reform, applied the devolution plan (assignment or transfer of central government powers without parliamentary approval) for Scotland and Wales. The Conservatives evaluated such a move of the Government as the beginning of the process of "Balkanization" in Britain, which will lead to increased conflict, nationalism and the fragmentation of the country. Scotland now has the right to introduce some form of taxes, unlike Wales, which was not entitled to tax.

In Canada, the political discussion on fiscal decentralization often resulted in the forwarding of the request for greater autonomy of some federal units. In order to avoid "Balkanization" in Canada in the best possible way, one of the offered solutions to the problem of Quebec was to strengthen independent tax systems of the members of the federation. Germany and Switzerland are in the process of consideration of reform of the equilibration that reduces disparities in the amount of public revenues of the federal units.

The World Bank clearly points out the importance of all the above, stating that the main factors that will enable the world's development in the first decade of this century include globalization (continuing integration of countries around the world) and localization (the desire for self-determination and the transfer of powers from the central level to lower levels of government). The report also notes that "globalization and localization," although at first glance may seem countervailing often derive from the same sources and reinforce one another. Regardless of the process of integration into the EU, the issue of fiscal federalism in the direction of decentralization is ongoing, both for the EU Member States, and for countries in transition.

\footnotetext{
${ }^{2}$ See in: t, A., Tranzicija i poreske reforme
} 
Macro-economic instability in many countries in transition with the inherited centralized way of managing the economy are the main aggravating circumstances to the establishment of an effective, fiscally decentralized system. In the framework of the comprehensive reforms of tax systems in countries in transition, special emphasis was placed on fiscal relations between different levels of government. The degree of decentralization in these countries is conditioned by a number of factors, not only economic, but also political, demographic, historical, and similar. Thus, it was shown that considerable autonomy in spending of income exists in the Czech Republic, Hungary, Poland and Slovakia, while in Bulgaria, Albania, Ukraine and Moldova priorities for public expenditure at the local level are usually determined by the central government. Giving the effective independence to local authorities to determine themselves the tax rate and the tax base for income which belong to them continues to represent one of the challenges faced by countries in transition.

In average, own taxes make up only $7.3 \%$ of their revenues, with the largest share in Slovakia (21\%), while Bulgaria, Latvia and Lithuania, do not really have their own income. Taxes attributable to local authorities include property taxes, fees for usage of goods of common interest and a number of additional taxes that have relatively little significance. Thus, for example, in 2002 Russia had twenty one types of such local taxes, but their sum in total tax revenues barely reached $0.5 \%$. On the other hand, in Hungary, the business tax, for which the tax base has a combination of payroll, capital and profits, yields $40.8 \%$ of revenues in total tax revenues. But practically in all the countries in transition the majority of the revenue of local authorities consists of outsourced (common) taxes, transfers from other levels of government as well as non-tax revenues.

The European Union encourages the policy of decentralization in its Member States and this orientation has lasted almost from the beginning of that association. But although the EU considers the decentralization of the Member States desirable, certain territorial and political structure of a country is not a condition for membership in the EU. The Union accepts the membership of the countries as they are in their territorial, political and fiscal terms, when they fulfill the other conditions necessary for membership. As a result, its members include very centralized and highly decentralized countries. General and highly conditional division of EU countries can be carried out via three groups in terms of territorial and political organization. Three countries are federal (Austria, Belgium, Germany), two regional (Italy, Spain), and twenty-two are unitary with various solutions. Some unitary countries have no regions except administrative and statistical (Latvia), while others have some form of region, whether they are regions with a historical background, or regions that have a historical basis (Dukedoms in Poland) or they are subsequently constituted as regions. These regions practically belong to the local level of government, together with municipalities and cities.

United Kingdom has four sub-state units of government (England, Scotland, Wales and Northern Ireland), which still have little jurisdiction but can possibly be independent states. United Kingdom formally does not fall within any of the three aforementioned groups and as such is a special case.

Data on EU countries suggest that these countries are (de)centralized in a very different degree. The level of government spending according to different levels of government is used as a measure of decentralization. Increased consumption at the level of the central government in relation to other levels of government means greater centralization.

When it comes to the level of government spending at the level of the central government in relation to the overall level of government spending, highly centralized countries are those that have 80 percent or more spending on government level. Centralized countries have spending of 20-30 percent, semi- 
centralized of 30-40 percent, decentralized of 40-50 percent, and highly decentralized of more than 50 percent of spending on lower government levels.

\section{THE PRACTICE OF DEVELOPED COUNTRIES}

In the USA, taxes are collected by hundreds of tax administrations. At the federal level there are three tax agencies: Alcohol and Tobacco Tax and Trade Bureau ${ }^{3}$, Internal Revenue Service $^{4}$ and US Customs and Border Patrol ${ }^{5}$. Roles of TTB and CBP are clear and easily understood on the basis of their names. The most important is of course the IRS which is in charge of all internal tax obligations of citizens and companies and does not fall under the jurisdiction of TTB. CBP is part of the Department of Homeland Security ${ }^{6}$, while the TTB is part of the Ministry of Justice. IRS has broad autonomy within the US Treasury. Each state has its own tax administration whose activities are defined by state laws and regulations. In most cases they bear the name of the Secretariat of Revenue or the Secretariat of Income Tax. Most states have harmonized regulations for taxes at the local and national level, making it easier to levying taxes and filing tax forms. The rules of filing tax forms by taxpayers are very different from country to country. Tax forms are submitted to the state administrations separate from the federal ones.

The Federal power has the largest share in the total public revenue in USA. The main source of public revenues of the federal budget and the state budgets is the progressive income tax, which is the backbone of the US tax system. The most significant tax revenues for the federal authorities come from the personal income tax and social security contributions. The federal government has a dominant place in the budgetary transfers in order to equilibrate amount of public revenues of the states in accordance with the achievement of a certain level of public services and a fairer distribution of the tax burden.

Table 44 - Share of different levels of government in the US public revenues (in \%)

\begin{tabular}{|l|l|l|l|l|} 
Types of public revenues & Total & $\begin{array}{l}\text { Federal } \\
\text { government }\end{array}$ & States & $\begin{array}{l}\text { Local } \\
\text { government }\end{array}$ \\
\hline 1. Tax revenues: & 100,0 & 56,8 & 26,2 & 17,0 \\
\hline - property tax & 100,0 & - & 3,8 & 96,2 \\
\hline - income tax & 100,0 & 82,0 & 16,3 & 1,7 \\
\hline - corporation income tax & 100,0 & 79,9 & 18,5 & 1,6 \\
\hline - sales tax and gross income & 100,0 & 24,0 & 63,3 & 12,7 \\
\hline - customs duties & 100,0 & 100,0 & - & - \\
\hline - retail sales tax on products and services & 100,0 & - & 83,0 & 17,0 \\
\hline - selective consumption tax & 100,0 & 40,3 & 50,1 & 9,6 \\
\hline - tax on inheritance and gifts & 100,0 & 71,4 & 28,4 & 0,2 \\
\hline 2. Social security and welfare & 100,0 & 75,8 & 21,3 & 2,9 \\
\hline - Social and Health Care & 100,0 & 100,0 & - & - \\
\hline - unemployment insurance & 100,0 & 1,1 & 98,7 & 0,2 \\
\hline - pension insurance & 100,0 & 5,2 & 79,4 & 15,4 \\
\hline Total public revenues & 100,0 & 56,8 & 24,6 & 18,6 \\
\hline
\end{tabular}

Source: R. W. Rachis, Revenue Raising Pouvrs, Practice, And Policy Coordination In The Federal System of the United States, Background Document, OECD Seminar: Fiscal Federalism in Economies in Transition, OECD, Paris, 1991, p. 7.

\footnotetext{
${ }^{3}$ Alcohol and Tobacco Tax and TRade Bureau, TTB

${ }^{4}$ Internal Revenue Service, IRS

${ }^{5}$ U.S. Customs and Border Patrol, CBP

${ }^{6}$ Department of Homeland Security
} 
The most important in the structure of total public revenues of the states are tax revenues from personal income tax, sales tax/gross income, retail sales tax on goods and services and excise tax on the consumption of gasoline, cigarettes and alcohol, while the property tax is most important for local government. In order to mitigate the regressive effects of the retail sales tax on goods and services, most states have exempted medicines and food from paying this tax.

Canada is a federal state which is composed of ten federal units (provinces) and three autonomous units which differ a lot according to the level of their economic development, and in which the model of fiscal federalism with the dominance of the federal (federal) fiscal sovereignty functions ${ }^{7}$.

In terms of the financing of politicalterritorial units in Canada, it can be said that the Federation is mainly financed by income from the personal income tax (46.7\% to $59.5 \%$ ), while other income yields significantly less funds: corporation profit tax (11,5do 20.9\%), VAT (12.8 to $16.9 \%$ ) and individual consumption taxes (around 8.1\% of revenues). The sub-central authorities are also largely financed by revenues from the personal income tax $(32.4 \%$ to $43.4 \%)$, followed by corporate income tax $(6.1 \%$ to $11.2 \%)$, retail sales tax (16.9 \% to $19.6 \%)$ and individual consumption tax $(3.5 \%$ to $16.8 \%)$.

The most important local government revenue is property tax, mainly the periodic property $\operatorname{tax}(78.1 \%$ to $88.1 \%)$, while the share of nonrecurrent taxes on property significantly less $(2.9 \%$ to $7.3 \%)$. Property tax revenues are being introduced at sub-central level, which are then, for the most part, given away to the local authorities. This means that it is common revenue of sub-central and local authorities. In relation to the property taxes, the share of other income in the total income of the local government is negligible (for example, a tax on the use of resources to carry out activities accounts for a share of only $1.3 \%$ to $2.1 \%$ ).
The provinces' significant revenues include also transfers from the federal budget to the budgets of provinces. Transfers, as a rule, are given due to unevenness of economic development in order to achieve a balance in the amount of income of provinces. There are three basic forms of these transfers:

- $\quad$ transfers that are given to balance the amount of tax revenues

transfers that serve to implement a national program of the Fund for health care and secondary education, and

- transfers that are given for the implementation of social assistance programs.

Transfers that are given in order to implement the program of balancing of tax revenues are intended to provide in all provinces a level of public services with the same tax burden. Assistance is provided to provinces whose amount of total tax revenue is under the established standards, or below the national average.

Transfers given to implement the policy of the Fund for national health care and secondary education are given to those provinces that can not provide their citizens such a level of public services that is consistent with national standards in the field of health care and education. Transfer of funds in order to realize a program of social assistance means that the central government bears part of the (half) costs incurred in implementation of this program. Transfers include nearly 5.2\% of the GDP of Canada (average 28\% of total tax revenues of provinces), which points to their importance in the system of financing the provinces.

Germany represents a federally regulated state in which power is divided into three levels: central government (federal government), sub-central level or the level of federal units (states) and the local government level where there are local communities (municipalities). Given the fact that Germany is a federal

${ }^{7}$ Constitution Act, 1867, Nelson, Political Science, Ottawa, 2001; T. J. Courchene, In praise of re- newed federalism, C. D. Howe Research Institute, Toronto, 1991; M. Sabia, The Experietice of Canada, Position Paper, OECD Seminar: Fiscal Federalism in Economies in Transition, OECD, 1991 
republic, authority to collect taxes is the federal government (Bund), Member States (Länder) and municipalities (Gemeinden) whose role in taxation is deferred and legally enshrined in the Constitution of 1949.

The most important taxes include income tax, business, corporation, trade tax and value added tax. Although Germany is a federal state, $95 \%$ tax represents tax at the federal level, which is still under article 116 of the Constitution, allocated as follows:

a) The Federal State retains exclusive revenues from customs duties, taxes on the flavored alcoholic beverages, automobiles, distilled drinks, oil and oil products, coffee, sparkling wine, electricity, tobacco and insurance, the so-called solidarity burden (tax for the development of the former East Germany).

b) Member States retain exclusive revenue from tax on heritage, tax on beer and gambling, tax on fire protection.

c) Municipalities retain only revenue from the tax on other drinks, dogs and inns and tax on real estate.

However, most of the revenues are income tax and value added tax (VAT) and some other taxes. Revenues from these taxes are distributed between the federal state and the member states on the basis of quotas ${ }^{8}$ : income tax accounts for $42.5 \%$ for the federal government, $42.5 \%$ for states and $15 \%$ for municipalities. The corporate income tax accounts for $50 \%$ to the federal government and $50 \%$ to states.

Member States pay to municipalities a part of revenues from other taxes. In addition there is compensation between rich and poor member states established by Article 107 of the German Constitution. Also, there is a strong co-ordination of fiscal policy implemented by the various levels of government.
German fiscal administration is divided into federal, state and municipal. The German Ministry of Finance issues regulations, in some cases written decrees implemented by local tax offices that belong to the states. The tax system in Germany is one of the most effective systems of Western Europe. One reason for this flattering evaluation is the developed system of education of financial human resources and profiles of expertise in state services.

For the financing of political-territorial units in Switzerland the most important revenues for the central government come from general sales tax $(28.3 \%$ to $35.7 \%)$ and personal income tax (23.9\% to $27.8 \%)$.

The cantons are, for the most part, financed by revenues from the personal income tax $(63.5 \%$ to $65.3 \%)$, while the share of other income is much lower - taxes on corporate profits $(10.2 \%$ to $14.2 \%)$, taxes on property (14.3\% to $18.2 \%)$ and individual consumption taxes $(5.8 \%$ to $6.9 \%)$.

Local authorities are mainly financed by income ceded by the Confederation and the cantons. In fact, the personal income tax $(73.2 \%$ to $76.3 \%)$ has the largest share, while the tax on corporate profits $(8.6 \%$ to $13.4 \%)$ and property taxes $(13.2 \%$ to $15,4 \%)$ yield much less revenues.

The tax administration consists of the Federal tax administration (SPA), the cantonal tax administrations and municipal tax unit.

The role of the SPA and the cantonal tax administrations is legally delimited by the Constitution that gives full right to the cantons to determine the tax rates at which it collects taxes and imposing new taxes except those that are already taxed at the federal level. At the same time, the cantons in accordance with their constitutions give municipalities the right to the collection of certain taxes, which varies from canton to canton. At the same time SPA and cantons carry out the

${ }^{8}$ Schwidetzky, W.D., A Comparison Of The Income Tax Systems In The United States And Germany, University Of Baltimore School Of Law 
collection of certain direct taxes. In order to avoid double or disproportionate taxation, in 1990 the Federal law on tax harmonization was adopted which led to harmonization of federal and cantonal tax rates on direct taxes, primarily the personal income tax and tax on corporate income.

\section{FINANCING OF LOCAL SELF- GOVERNMENT IN OUR COUNTRY}

Local governments are mainly responsible for local administrative services (such as home records of citizens, building permits, land register, and a certain degree of business licenses); local utilities and infrastructure facilities for water and sewerage, solid waste, and local roads; and certain features of education (in RS, preschool education and capital investments in high schools; in $\mathrm{FBiH}$, certain expenditures on preschool and primary education in some cantons), culture and sport, social assistance and financing in one of the health centers (in the Republic of Srpska).

In order for local governments to successfully carry out their activities within the framework of the law-delegated jurisdictions, they must have adequate financial resources. The relationship between public revenues and public expenditures with local communities is far stronger than at the state level (state can relatively easily increase spending without increasing revenues), and the decrease in tax revenues, as a measure aimed at improving economic opportunities and attracting investors, inevitably calls into question the level and quality of local public services.

The Law on Principles of Local SelfGovernment of FBiH and the Law on Local Self-Government of the Republic of Srpska distinguish several categories of revenue of local governments.

Two main groups of revenues are tax revenues and non-tax revenues. Other income groups that often occur are grants from higher levels of government (entities, cantons), grants and loans.
The growth of local tax revenue is supportive factor for the local authorities, as it allows higher budget spending and higher fulfillment of general needs. However, in $\mathrm{BiH}$ local taxes practically do not exist, because they are all under the jurisdiction of the entities or the state. Mostly, entities which introduce them decide on rates, bases, exemptions and deductions, and charge them by care of the entity tax administrations. The revenue of some of them was transferred to the local communities, but they have no influence on the elements of taxation, including the amount of the tax rates and collection control. Local governments are characterized by a high level of dependence on the income transferred to them from the higher levels of government, so they have no ability to affect the height of the key sources of funding, except some local taxes and fees.

In order to finance the local government jurisdictions, the budget of the local government units is entitled to revenue and earnings, as follows:

1) taxes in the part established by law: part of the revenue from indirect taxes, personal income tax; property tax; tax on inheritance and gift; tax on transfer of absolute rights;

2) fees: administrative, utilities and taxes;

3) fees for the use of goods of common interest, in accordance with the law;

4) grants and transfers;

5) other public revenue: interest income; income from leasing, or the use of real estate and movable government-owned property, used by local governments or the authorities, organizations and services of the local government units and indirect beneficiaries of its budget; income from leasing, or the use of real estate and movable property owned by local governments, in accordance with the law; revenues obtained from the activities by authorities, organizations and services of the local self-government; income generated from fines imposed in misdemeanor 
proceedings for misdemeanors prescribed by the assembly of the local self-government and confiscated assets in this process; revenues from concession fee in accordance with the law; other income stipulated by law;

6) proceeds: income from the sale of real estate owned by local government; proceeds from the sale of movable state-owned property used by authorities, organizations and services of the local self-government; proceeds from the sale of movable property owned by local governments used by the bodies, organizations and services of the local self-government; proceeds from the sale of stockpiles; proceeds from borrowing; proceeds from the sale of financial assets; other proceeds stipulated by law. delegating authority to local government.

Local self-government is achieved in municipalities and cities, and it is carried out by the citizens and local government bodies. The municipality is the basic unit of local government, which is formed for populated places, for one or more settlements. The municipal authorities perform tasks that belong to the local government, the Mayor of the municipality and the municipal assembly. All the activities of municipalities are divided into: independent and delegated affairs of the state administration.

According to the Law on Budget System of the Republic of Srpska, revenues that are divided between the republic budget, the budget of municipalities and cities and other users are

Table 11 Structure of revenues of selected cities in $\mathrm{BiH}$ in 2014 (in KM mil.)

\begin{tabular}{|l|l|l|l|l|}
\hline & \multicolumn{1}{|c|}{ Mostar } & \multicolumn{1}{|c|}{ Tuzla } & Banja Luka & Sarajevo \\
\hline Revenue & 48.6 & 45.3 & 118.0 & 90.9 \\
\hline Tax revenue & 21.5 & 22.7 & 65.6 & 36.2 \\
\hline $\begin{array}{l}\text { Taxes on income of individuals and } \\
\text { companies }\end{array}$ & 30.0 & 19.7 & 1.2 & 63.7 \\
\hline Taxes on wages and labor & 25.3 & 201.6 & 14.7 & $/$ \\
\hline Property tax & 4.2 & 4.3 & 5.5 & 18.4 \\
\hline Domestic taxes on goods and services & 9.2 & 38.3 & 0.3 & $/$ \\
\hline Income tax & 6.6 & 7.2 & & 1.7 \\
\hline Revenues from indirect taxes & 10.6 & 10.8 & 44.8 & 16.0 \\
\hline Other taxes & 2.7 & 9.5 & 33.4 & 34.4 \\
\hline Non-tax revenues & 25.5 & 19.0 & 38.7 & 41.8 \\
\hline Transfers and grants & 1.5 & 3.5 & 4.0 & 12.2 \\
\hline Proceeds from property & 0 & 0 & 4.1 & 0.5 \\
\hline Proceeds from borrowing & 0 & 0 & 5.5 & 0 \\
\hline
\end{tabular}

Source: Source: http://javnefinansije.cpi.bal

The comparison of the budget of the Republic of Srpska shows that the revenues of municipalities and cities in the Republic of Srpska are more dependent on indirect taxes, unlike the $\mathrm{FBiH}$, while grants have a much larger share in the structure of the municipality revenues in the Federation than in RS. Also, cities and municipalities in the Republic of Srpska have significantly higher debt levels.

\section{REPUBLIC OF SRPSKA}

The Republic of Srpska consists of 57 municipalities and 6 cities, and has a centralized structure and the low level of fiscal the revenues from indirect taxes paid into the budget of the Republic of Srpska from the Single Account of the Indirect Taxation Authority, of which after the separation of part of the funds for external debt, $24 \%$ is paid (back) to municipality and city budgets.

The local government units are characterized by a high level of dependence of their revenues from indirect taxes (over 50\%) that are transferred to them from higher levels of government, and therefore are not able to affect the amount of the key sources of funding. Municipal budgets realize other income through: 
1) The income tax:

a. tax on income from self-employment and

b. personal income tax, which after allocation of funds for reserves in the amount of $10 \%$ for the return of the impairment of the tax base are shared between the state budget and the budgets of municipalities and cities in the scale of $75: 25$;

2) Compensation for the change of use of agricultural land, which is shared between the state budget and the budgets of municipalities and cities in the scale of 30:70;

3) The royalty fee for use of mineral resources, which is divided between the state budget and the budgets of municipalities and cities in the scale of 30:70;

4) special water charges, as follows:

a. fees for the abstraction of surface water and groundwater,

b. fees for electricity generated by hydropower,

c. fees for the extraction of material from watercourses, which are shared between the state budget and the budgets of municipalities and cities in the scale 70:30 and

d) compensation for protection against waters, which is divided between the state budget and budgets of municipalities and cities and the Fund for Environmental Protection of the Republic of Srpska in the scale 55:30:15;

5) Confiscated assets and the proceeds from the sale of seized items from the jurisdiction of the Republic Administration for Inspection Affairs, which is shared between the state budget and the budgets of municipalities and cities in the proportion of 70:30. Thus, the practice to a new set of laws, which consisted in the fact that the criteria in the allocation of shared taxes were determined by higher levels of government, while defining the participation of certain levels in the distribution and collection of joint taxes and control of the application of legislation, has not essentially altered a lot.
The most significant changes consist in the complete transfer of competences to local governments over tax on real estate. Law on Budget System of the Republic of Srpska stipulates that local governments, as its original income, are entitled to the following revenues realized on their territory:

1) property tax,

2) fines imposed in misdemeanor proceedings for offenses set forth by the decisions of municipalities,

3 ) municipal administrative fees,

4) municipal taxes, there are a total of 15 types of municipal tax, and as a special one on the city territory - city administrative fee,

5) special water charges - charges for protection from waters,

6) municipal fees for the use of natural and other goods of common interest:

a) income from land rents,

b) fees: for landscaping and use of building land, forest utilization - funds for the development of underdeveloped areas of the municipality realized from the sale of wood products, the use of municipal resources of common interest and use of mineral water,

7) tax on winnings from games of chance,

8) other income:

a) income from donations and revenues that budget users realize by performance of regular and additional activities, which is not contrary to the law regulating their activities, as a percentage determined by the decision on budget execution and

b) other municipal revenues.

Among mentioned revenue of local governments especially important are local utility taxes and income from real estate tax. These revenues are most important for most local governments not only in terms of the balance sheet, but also as more important local source of public revenue. 
But it is also interesting that in practice revenues based on voluntary contributions have been certainly forgotten. A voluntary contribution represents relatively significant local fiscal revenue of strictly earmarked character, and it has had a long tradition in this region. Its specificity is reflected in the fact that a decision on its introduction is made by citizens through direct personal voting on the referendum and, as a rule, it is time-limited public revenue (collected for a certain number of years).

The original public revenues, however, are often not sufficient to ensure the financing of local public expenditures, and the local governments may make independent borrowing at home and abroad, for the purpose of financing capital investment expenditures and/or cover the deficit. The Ministry approves the amount of debt that exceeds this limit.

Cities and municipalities may also borrow from the state budget, with the consent of the Ministry, for the following: 1. Investment expenditure and 2. Cover of short-term deficits caused by unforeseen expenses or due to fluctuations of liquid assets during the fiscal year. The total amount of borrowings during the fiscal year must be returned to the Republic budget by 31 December of the same year. Local governments can borrow long term only if in the period of debt the total amount due for repayment after the proposed debt and the overall matured, and the outstanding existing debt, in any coming year does not exceed $18 \%$ of their regular income realized in the previous fiscal year. Proposal of Decision on borrowing is made by the municipal assembly, or city.

Receipts and expenditures of the Republic of Srpska municipal debt in 2014 are:

- Proceeds from short-term borrowings KM 108.1 million

- Proceeds from long-term borrowings KM 379.4 million and

- Repayment of debts in 2014 were KM 539.8 million.

\subsection{FISCAL DEPENDENCE OF MUNICIPALITIES ON HIGHER LEVELS OF GOVERNMENT}

Although the system of shared revenues to local governments guarantees some certainty in generating revenues, a particular problem arises due to the fact that for a significant number of municipalities the amount of transfers from the budget of the higher levels of government is very important source of income, and the unit is not able to influence the amount of shared revenues of local selfgovernment. The consequence of such a situation is extreme diversity in the heights of taxes imposed by autonomous decision by local governments, whether it refers to administrative or communal taxes.

The introduction of the transfer system as one of the dominant sources of income of local government units, resulted in fiscal dependence of local governments from the central (entity) authorities, making it difficult to wear revenue in accordance with local preferences and narrowing fiscal decentralization.

The measure of fiscal decentralization is best expressed by the share of local public revenues in total public revenues of each specific country and, in particular, the structure of local revenues from the point of origin. Thus, by comparison, in the early 2000 s, the share of local revenues in total public revenues in unitary regulated OECD countries was $13.8 \%$ of total revenues. The data show that there has been a strengthening of fiscal decentralization in unitary OECD countries, since the share of local public revenues increased by nearly ten percent ${ }^{9}$.

The structure of local revenues in OECD member countries is dominated by the original local public revenues (over $68 \%$ in unitary and close to $70 \%$ in federal states), while the share of assigned revenues in both groups is about $27 \%$. The share of additional public revenue is modest: in unitary OECD

\footnotetext{
${ }^{9}$ Statistiques des recettes publiques, OECD, Paris, 2004, p. 210.
} 
member countries it is around $5 \%$, and in federal approximately it is $3 \%$ of total local public revenue.

Contrary to the aforementioned structures of local public revenues from the point of origin represented in the OECD member countries, data for the Republic of Srpska and the Federation of $\mathrm{BiH}$ indicate significant fiscal and financial dependence of local communities on remittances of funds from higher levels of government - entities and cantons. Quite unreliable data for the period up to 2014 show that the share of direct revenues in total public revenues of local governments, on average, in $\mathrm{BiH}$, was just above $45 \%$, while the share of transferred ones was about $55 \%$ of total public revenue of local governments. ${ }^{10}$

The RS budget occupies about $1 / 4$ of the consolidated budget of $\mathrm{BiH}$. Republic of Srpska collects $25.8 \%$ of total public revenues, and consumes $28.3 \%$ of total public expenditure. From the standpoint of fiscal decentralization, it is noticeable that the Republic of Srpska is extremely centralized because the central level participates in public revenues and expenditures over $60 \%$. We can draw conclusions about the scope of its decentralization since public funds spend over $25 \%$ of the budget, and a large number of social functions (social protection, education, schools) are left to the municipalities that have at their disposal several times less funding than the entity. This also, in turn, shows a narrowing of the level of fiscal decentralization in Srpska in terms of the influence of local communities on the amount rather than the very amount of public revenue funds.

We can conclude, based on everything that $\mathrm{BiH}$ is extremely decentralized, sociopolitical structure, but it has a very centralized fiscal structure at the intermediate level entity and cantonal level, with a very uneven level of development between different lower forms of socio-political organization (cantons and municipalities). Economically developed are mainly communities and municipalities with a high degree of urbanization (cities), while in contrast to a small number of them stands a large number of underdeveloped municipalities. Both entities, suffer from extremely uneven degree of regional economic development, which is manifested in emigration - the concentration of population in cities, exacerbating regional divides. In any case, there is an evident disparity between the financial capacity of municipalities and their responsibilities and the needs of local population.

${ }^{10}$ Ibid., SAFE, 2015 


\section{CONCLUSION}

One of the fundamental economic reasons for joining the fiscal decentralization concerns the changes in individual customer preferences in the selection of different public good. Decentralized power is able to be better and more fully informed about the needs and requirements of individuals, which can contribute to meeting public needs. Besides, the satisfaction and the provision of local services is less expensive because the overall costs and control costs are lower. In order to make the central government able to act effectively, it is necessary first of all to have appropriate instruments, including fiscal. If the central government decentralized tax system too much it could reduce its ability to use fiscal policy to achieve macroeconomic objectives.

Great mobility of tax base between different levels of government significantly complicates taxation at the local level, and distorts the efficient allocation of production resources. Therefore, the public revenues (taxes) with less mobile tax base for taxation are more suited to local levels of government to avoid moving of the taxpayers in the local communities where tax rates are lower. These public revenues (taxes) include taxes on property, primarily taxes on real estate. The unequal distribution of the tax base suggests that it is economically efficient that federal entities tax natural resources (e.g. oil or natural gas). If such resources are unevenly distributed between the federal units, there is an economic justification for the central government to tax extra income, with the intention to avoid sub-optimality in the allocation of natural factors.
The transfer of fiscal powers occur even in "countries that have always been centralized," such as the Kingdoms of Jordan and Morocco, countries of Central and Eastern Europe - the former socialist countries, the People's Republic of China, military regimes such as Pakistan, countries like Thailand that view decentralization as an effective strategy to improve the delivery of public services after the financial crisis, in national states that are trying to avoid the centrifugal forces of separatism, like Russia and Indonesia, and South American countries, where there is increasingly stronger participation of citizens and authorities in the budget process. The transfer of fiscal powers to lower levels of government is a trend that is also encouraged by the European Union, although the existing studies do not prove a direct correlation between the degree of fiscal decentralization and GDP growth. Thus, fiscal decentralization remains a political rather than economic issue.

The issue of fiscal decentralization is still purely political issue. In Bosnia and Herzegovina in the postwar period it was difficult, due to frequent changes in the model of financing of local governments and specific socio-economic relations, to determine the share of local revenues in total public revenues. The data for $\mathrm{BiH}$ show that the degree of fiscal decentralization in $\mathrm{BiH}$ is higher on the secondary government levels, but not at the level of local communities which is the case with the unitary OECD countries. 


\section{Literature}

1. Stojanović, A., Stakić, B. i Heljić, A., Fiskalni systemic, Revision, Sarajevo, 2016.

2. Radii, M., Raičević,B., Javne finansije teorija $i$ praksa, Ekonomski fakultet, Novi Sad, 2008.

3. Stojanović, A., Tranzicija i poreske reforme, Revicon, Sarajevo, 2008

4. Constitution Act, 1867, Nelson, Political Science, Ottawa, 2001;

5. T. J. Courchene, In praise of re-newed federalism, C. D. Howe Research Institute, Toronto, 1991;
6. M. Sabia, The Experietice of Canada, Position Paper, OECD Seminar: Fiscal Federalism in Economies in Transition, OECD, 1991.

7. Schwidetzky, W.D., A Comparison Of The Income Tax Systems In The United States And Germany, University Of Baltimore School of Law

8. Statistiques des recettes publiques, OECD, Paris, 2004.

9. SAFE, Projekat Vlade Kraljevine Švedske, Sarajevo, 2015. 